\title{
In search of lost hybridity: the French Daniel Deronda
}

\author{
ALAIN J.E WOLF \\ University of East Anglia, Norwich, England \\ a.wolf@uea.ac.uk
}

\begin{abstract}
Starting from a set of examples of borrowings from French in George Eliot's Daniel Deronda, I explore the various ways in which the characters' and narrator's use of mixed English-French utterances generate inferences which make the transcending of their mono-cultural self possible. I go on to argue that in Jumeau's recent French translation of the novel, the reader is not given access to those inferences, resulting in the erasing of an Anglo-European, cosmopolitan identity.
\end{abstract}

Keywords

Linguistic borrowing, langue intermédiaire, composite idiom, cosmopolitan identity, implied meaning.

\section{Introduction}

George Eliot has often been seen as writing for a cosmopolitan audience (Couch,1967; Rignall, 1997; Seeber, 2000) and her characters' Anglo-European identities go beyond a national self (Seeber, 2000 : 18). In Daniel Deronda, in particular, George Eliot consistently has both her characters and her narrator peppering their talk with French words thus highlighting the characters' cosmopolitan identity. In an earlier article (see Wolf, 2015), I called this phenomenon of borrowing from French a composite idiom, or in Proust's words 'une langue intermédiaire' which I further attempted to define as a form of inferencing. In other words, when the characters or the narrator borrow from French they generate inferences which show them transcending their mono-cultural selves.

Consider the following example, the description early in the novel of Gwendolen who, playing roulette in a casino, starts to lose after encountering Deronda's gaze:

(1) She had begun to believe in her luck, others had begun to believe in it: she had visions of being followed by a cortège who would worship her as a goddess of luck and watch her play as a directing augury.

(Eliot, 2000:7) 
The word cortège borrowed from French via the Italian corteggio in 1622 (Rey, 2006) designated a procession of people in a ceremony, the verb corteggiare denoting the activity of accompanying a person of importance to whom honour was due. The narrator here uses it in the context of a fashionable continental spa resort, Leubronn, where 'distant varieties of the European type' (Eliot, 2000:4) congregated in the pursuit of gambling. The narrator's use of the French word points to a need to depict a distinctively European situation.

A worthwhile point of departure then is briefly to re-visit the notion of borrowing in the context of cosmopolitan identity, polyphony and inferencing. I will then explore the recent French translation of the novel by Jumeau (2010) to analyse what happens when composite utterances, i.e. utterances which combine the use of French and English, are translated into only one of the languages of the mixed utterances.

\section{The composite idiom, dialogical identity and polyphony: decentering the self}

The phenomenon of borrowing from another language is wide-spread, not only among bilingual speakers, but also in the context of literature. It has been variously described by linguists (Muysken, 2000, Rampton, 1996) but the question which is less often addressed is how borrowing relates to an understanding of identity as polyphonic. Hermans (2014:291) in his presentation of Clement Egerton's translation of the $17^{\text {th }}$ century Chinese erotic novel Jin Ping Mei comes closest to an analysis of borrowing as voice, 'an index of moral censure' (Hermans, 2014:291). The way censure functions in this context is by the translator, Clement Egerton 'reserving some passages [in Latin, my addition] for the exclusive delectation of a cultural elite presumed to be morally as well as intellectually robust' (Hermans, 2014:291). Hermans (2014: 291) concludes that the choice of which passage is to be veiled from the average reader by the use of a foreign borrowing reveals the translator's positioning.

My aim here differs slightly from that of Hermans in the sense that I am observing code-switching in the source text (rather than in a translation), and analysing its disappearance in translation. I also want to suggest that all utterances, whether translated or not, are a staging of composite utterances. In attempting to formulate a concept of utterance understanding, it was Ducrot (1984: 193), inspired by Bakhtin (1981), who showed how communication is a matter of realising that any discourse is a theatrical staging of several voices. In the act of uttering, Ducrot argued (1984:193), a speaker controls the voices of her/his characters and presents us with their attitudes and beliefs. He identified three instances of 'voice': the speaking subject (sujet parlant) utters the discourse in the physical sense of the word, the speaker (locuteur) is responsible for the act of utterance and the enunciators (énonciateurs) are those real or imagined entities whose points of view (points de vue) are expressed in discourse. The speaker (locuteur) can be the same as the enunciator though this is not necessarily the case: the 'I' in an utterance such as 
'So I'm stupid, am I?' is unlikely to express the opinion of the speaker. Rather, we interpret it as an echo of a viewpoint expressed by an enunciator, in this case the entity represented by 'you'.

The implications of this theatrical staging of utterances within one speaker are far reaching for the use of composite utterances. Indeed, when characters in Daniel Deronda use a composite idiom, it may be argued that they present their identity through the perspective of enunciators from another language background. In other words, the traces of the enunciator's discourse are manifest in the speaker's use of a composite utterance. Ducrot (1984) goes on to say that utterances are 'polyphonic', i.e. that they contain within themselves the seeds of dialogue, a layering of consciousness and a decentering of the self.

A polyphonic cosmopolitan identity then emerges when speakers integrate the opinions and viewpoints of enunciators within their own discourse by means of a composite/mixed idiom, i.e. an utterance which seems to belong to a speaker from another language background by its syntax, its vocabulary and its inferences. It is, in Bakhtin's (1981:304) words, a double-accented, double styled hybrid construction, one which 'contains mixed within it two utterances, two manners of speaking, two styles, two

'languages', two semantic and axiological belief systems' (Bakhtin, 1981: 304). This process of bringing different languages in contact with one another illuminates one language by means of another, and brings about what Bakhtin (1981:367) refers to as a 'semantic decentering of the ideological world, a certain homelessness of literary consciousness'.

\section{The composite idiom: inferences, semantic intentions and voices}

Interestingly, faced with a writer's or a speaker's switch into another language readers are required to engage in what I shall refer to as a calculus of interpretation. This concept, which owes much to the field of pragmatics, is the idea that speakers and hearers (and writers and readers) often have to engage in making hypotheses about what they can be expected to know based on a given context of situation. This is because much of what is communicated is often implicitly conveyed, rather than actually said. For example, student A may reply to student B's invitation to a party on Monday night by saying indirectly: 'my last exam is on Tuesday', thereby implying 'I can't come'. Similarly, when faced with a mixed utterance, readers engage in this type of inferencing based on the context provided by the two languages used. Through this process, they access a number of accessible hypotheses which I shall present below. It must be noted that this calculus of interpretation is necessarily dynamic and loose and that some hypotheses are more easily accessed than others. The important point here is that a mixed utterance inserts 'a new semantic intention into a discourse which already has an intention of its own and so such a discourse [...] must be seen as belonging to someone else. In one discourse, two semantic intentions appear, two voices' (Bakhtin, 1984: 189, cited in Rampton, 1998: 304). In the words of Rampton 
(1998:304) this kind of language crossing involves 'an authentic expression of their [the speakers'] identity in acts of serious self-contextualisation'.

\section{George Eliot's 'langue intermédiaire'}

Daniel Deronda has been seen as exceptional among George Eliot's novels in that it begs for comparison with the novels of other European writers, namely those of Balzac and Proust (Rignall, 2000:211). The claim here is not that George Eliot was directly influenced by those writers, but rather that there were affinities with the French writers which were a 'measure of the bold new departure that Deronda represents' (Rignall, 2000:211). This is because like Balzac and Proust, Daniel Deronda focuses on the cosmopolitan world of the rich and its 'formal qualities' (Rignall, 2000:212). Deronda, concludes Rignall (2000:223), has ironic boldness which is far divorced from the conservative spirit detected by Proust in George Eliot's earlier work, and it is with this quality of taking the reader on journeys of unknown imagination in mind that I have examined her use of the composite idiom (see Wolf, 2015).

I have recorded approximately 74 occurrences of language mixing in the novel ${ }^{\mathrm{i}}$, the majority of which were from the perspective of narratorial comment, 45 occurrences, i.e. $61 \%$ of the total number of occurrences (see table below). Of these, 51\% were narratorial comments about characters, 9\% were general narratorial comments. Language crossings issuing from characters' speech accounted for 29 occurrences, i.e. $39 \%$ of the total number of occurrences (74). Of these, 9 composite utterances issued from Gwendolen (31\%), 5 from Hans Meyrick (17\%), 3 from Daniel Deronda (9\%), 3 from Sir Hugo (9\%), 2 from Klesmer (7\%), 1 from Mirah (3\%), 1 from Grandcourt (3\%), 1 from Mrs Arrowpoint (3\%), 1 from Lady Brackenshaw (3\%), 1 from Gwendolen's mother (3\%), 1 from a group of minor bystanders (3\%), 1 from Lush (3\%), 1 from Mr Vandernoodt (3\%), 1 from a minor character (3\%). Of these, the majority were in direct speech (25), 3 from Gwendolen were in Free Indirect Speech and 1 from Mirah was a narrative report of a speech act.

\begin{tabular}{|l|l|l|}
\hline $\begin{array}{l}\text { Page number }+ \\
\text { Occurrence }\end{array}$ & Expression & Context \\
\hline $7(1)$ & A cortège & Narrator about Gwendolen \\
\hline $8(2)$ & $\begin{array}{l}\text { a) Faites vos jeux, Mesdames } \\
\text { et messieurs. } \\
\text { b) Le jeu ne va plus }\end{array}$ & Narration \\
\hline $9(3)$ & $\begin{array}{l}\text { a) nez retroussé } \\
\text { b) ensemble }\end{array}$ & $\begin{array}{l}\text { Character: Minor group of anonymous } \\
\text { characters seated at a }\end{array}$ \\
\hline
\end{tabular}




\begin{tabular}{|c|c|c|}
\hline & $\begin{array}{l}\text { c) ensemble du serpent } \\
\text { d) comme il faut } \\
\text { e) Russie }\end{array}$ & casino about Gwendolen \\
\hline $11(4)$ & Rôle & $\begin{array}{l}\text { Character: } \\
\text { Minor companion of } \\
\text { Gwendolen at the casino }\end{array}$ \\
\hline $17(5)$ & Salon & Narration about Gwendolen \\
\hline $18(6)$ & Salon & Narration about Gwendolen \\
\hline $28(7)$ & Rôle & Character: Gwendolen about her sister \\
\hline $45(8)$ & Carte-de-visite & $\begin{array}{l}\text { Narration about Miss } \\
\text { Arrowpoint }\end{array}$ \\
\hline $46(9)$ & Tête-à- tête & $\begin{array}{l}\text { Narration about Mrs } \\
\text { Arrowpoint }\end{array}$ \\
\hline $56(10)$ & Tableaux vivants & Narration about Gwendolen \\
\hline $101(11)$ & $\begin{array}{l}\text { a) tu seras heureuse, ma chère } \\
\text { b Oui, maman comme toi }\end{array}$ & $\begin{array}{l}\text { Character: Gwendolen's mother citing } \\
\text { Mme Roland }\end{array}$ \\
\hline $102(12)$ & Change de linge & Character: Gwendolen \\
\hline $113(13)$ & En règle & $\begin{array}{l}\text { Character: Mrs Arrowpoint } \\
\text { about her daughter }\end{array}$ \\
\hline $126(14)$ & A fellow without 'esprit' & Character: Klesmer \\
\hline $129(15)$ & Au désespoir & $\begin{array}{l}\text { Character: Lady Brackenshaw } \\
\text { To Gwendolen }\end{array}$ \\
\hline $147(16)$ & En suite & Character/narration FIS Gwendolen \\
\hline $149(17)$ & Distingué & $\begin{array}{l}\text { Character: Gwendolen about } \\
\text { Grandcourt }\end{array}$ \\
\hline $155(18)$ & Nonchalance & Narration about Lush \\
\hline $168(19)$ & Opera bouffe & $\begin{array}{l}\text { Narration about Gwendolen } \\
\text { And cultural code }\end{array}$ \\
\hline $174(20)$ & Table d'hôte & Narration \\
\hline $176(21)$ & Salon & Narration \\
\hline $177(22)$ & $\begin{array}{l}\text { That girl has }[\ldots] \\
\text { De l'imprévu }\end{array}$ & $\begin{array}{l}\text { Character: Sir Hugo } \\
\text { about Gwendolen }\end{array}$ \\
\hline $177(23)$ & Moi-je suis ancêtre & Character: Sir Hugo citing Napoleon \\
\hline $216(24)$ & À la chinoise & Narration about the Meyrick girls \\
\hline $216(25)$ & Histoire d'un Conscrit & Narratorial quotation \\
\hline $235(26)$ & He called me 'petit ange' & Character's report: Mirah (not italicised) \\
\hline $260(27)$ & Ennui & Narration \\
\hline $261(28)$ & Brusquerie & Narration about Klesmer \\
\hline $266(29)$ & Mésalliance & Character: Klesmer \\
\hline
\end{tabular}




\begin{tabular}{|c|c|c|}
\hline $266(30)$ & Couvert & Narration \\
\hline $287(31)$ & Protégée & Character/narration Gwendolen FIS \\
\hline $298(32)$ & Éclat & Narration about Gwendolen \\
\hline $302(33)$ & Nécessaire & Narration about Gwendolen \\
\hline $304(34)$ & Cortège & Narration \\
\hline $305(35)$ & Traits de moeurs & Narration about Sir Hugo \\
\hline $309(36)$ & A 'sou' & Character Lush \\
\hline $328(37)$ & Amour propre & Narration about Grandcourt \\
\hline $344(38)$ & Trousseau & Narration about Gwendolen \\
\hline $373(39)$ & Physique & Narration about Mrs Glasher \\
\hline $377(40)$ & Timbre & Narration about Mrs Glasher \\
\hline $389(41)$ & Éclat & FIS Gwendolen \\
\hline $398(42)$ & Ennui & Narration about Deronda \\
\hline $402(43)$ & Morale & Narration about Deronda \\
\hline $426(44)$ & Congé & Narration about Deronda \\
\hline $432(45)$ & Physique & Narration about Jacob \\
\hline $434(46)$ & Rouleau & Narration about Jewish grandmother \\
\hline $446(47)$ & Nonchalant & Narration about Mr Vandernoodt \\
\hline $448(48)$ & Mésalliance & Character Deronda \\
\hline $450(49)$ & Entrée & Narration about Deronda \\
\hline $455(50)$ & Tête-à- tête & Narration about Deronda \\
\hline $459(51)$ & naïveté & Narration about Deronda \\
\hline $463(52)$ & Démangeaison & Character: Sir Hugo \\
\hline $464(53)$ & Tête-à- tête & Narration about a party of people \\
\hline $464(54)$ & $\begin{array}{l}\text { fat (from Provençal (stupid, mad) and Latin } \\
\text { 'fatuus' (without taste)). }\end{array}$ & Character Grandcourt \\
\hline $464(55)$ & Fat & Character Gwendolen \\
\hline $478(56)$ & Faux pas & Character: Mr Vandernoodt \\
\hline $504(57)$ & Atelier & Narration about Deronda \\
\hline $506(58)$ & Le néant & Character Hans Meyrick \\
\hline $512(59)$ & Persiflage & Character: Deronda \\
\hline $518(60)$ & Physique & Character: Deronda \\
\hline $532(61)$ & Pièce de résistance & Narration about the Meyricks \\
\hline $540(62)$ & Rôle & Character: Hans Meyrick \\
\hline $540(63)$ & Chiffons & Character: Hans Meyrick \\
\hline $621(64)$ & Protégée & Narration about Gwendolen \\
\hline $625(65)$ & Physique & Character: Hans Meyrick \\
\hline $649(66)$ & pâté de foie gras & Character: Gwendolen \\
\hline $649(67)$ & Ennui & Character: Gwendolen \\
\hline
\end{tabular}




\begin{tabular}{|l|l|l|}
\hline $711(68)$ & À propos & Character: Hans Meyrick \\
\hline $714(69)$ & naïve & Narration about Deronda \\
\hline $743(70)$ & Ennui & Narration about Gwendolen \\
\hline $752(71)$ & Milord & Narration about group \\
\hline $758(72)$ & Milady & Narration about a group \\
\hline $820(73)$ & Portemonnaie & Narration about Mirah \\
\hline $862(74)$ & Roulette & Narration about Lapidoth \\
\hline
\end{tabular}

(Table 1: a list of French lexis in Daniel Deronda)

\section{An analysis of mixed utterances in narrator's comments and their translation into French}

There are a number of ways to approach the issue of borrowing in Daniel Deronda, but let me begin with three examples from the narrator's comments which best illustrate the use of mixed utterances and their effect once they have been translated into French. The first example I shall consider is the one I introduced earlier of Gwendolen playing roulette in a casino:

(2) She had begun to believe in her luck, others had begun to believe in it: she had visions of being followed by a cortège who would worship her as a goddess of luck and watch her play as a directing augury.

I observed (Wolf, 2015) that the use of the French word resulted in a mixed code which enabled the narrator to depict a distinctively European situation beyond the boundaries of the parochial and the monolingual. The narrator also uses the word figuratively to describe how Deronda would not have a man like Grandcourt suppose himself envied by him. However, as Eliot observes (2000:304), 'there is no guarding against interpretation' and it turns out that Grandcourt did believe Deronda to be envious of him:

(3) An imaginary envy, the idea that others feel their comparative deficiency, is the ordinary cortège of egoism; and his pet dogs were not the only beings that Grandcourt liked to feel his power over in making them jealous.

(Daniel Deronda: 304)

The Dictionnaire Historique de la Langue Française (2006:905) tells us that the word 'cortège' is borrowed from Italian 'corte' (court, courtesan) to denote a group of people following after an important person in order to render him or her homage. The word is also used of a file of people without the idea of worship being attached to it. This is the more usual meaning in contemporary French (Rey, 2006:905). 
A metaphorical use of the word can also be traced as far back as 1755 to express the idea of contiguity between entities as in the expression 'un cortège d'harmoniques' in music (Rey, 2006:905).

The recent 2010 translation of George Eliot's work by Alain Jumeau preserves the French word with a paratextual asterisk following it to indicate that it was in French in the source text:

(4) Elle avait commencé à croire à sa chance, d'autres avaient commencé à y croire : elle se voyait suivie par un cortège* d'admirateurs qui l'adoreraient comme une déesse de la chance et la regarderaient jouer comme un augure à suivre.

Despite the presence of the asterisk, the borrowing from French present in the source text disappears in the translated text. The consequence of this is that instead of being presented with a double-styled hybrid construction (see Bakhtin, 1981), the French reader is faced with a text that has become essentially monolingual. A whole range of inferences could be derived by the English reader, namely that Gwendolen finds herself in a distinctively European situation, hence the use of French. The other inference that can be drawn from the use of 'cortège' is that she was worshipped by continental admirers. We know this to be an inference, i.e. a recovery of meaning which goes beyond that which is merely said, because the word 'admirers' is not actually mentioned in the source text, i.e. 'she had visions of being followed by a cortège who would worship her as a goddess of luck'. Because the translated text has become monolingual, the distinctively European context and the attendant heteroglossia are attenuated. Further, the translator adds the phrase 'd'admirateurs' to the word 'cortège', i.e. by means of the translational strategy of explicitation, he turns what was a loose inference into an utterance that is not only explicitly communicated, but is also an instance of a particularised translation. The worshipful procession of people in the source text becomes a file of admiring men, 'admirateurs' being in the masculine form in French. Finally, the translation uses the word 'cortège' in its contemporary sense of procession without the connotation of worship. Thus, all the French readers can recover is that Gwendolen, having become popular for her winnings, is followed by a procession of male admirers.

Likewise, the word 'cortège' in 'Une jalousie imaginaire et l'idée que d'autres ressentent leur infériorité relative forment le cortège* ordinaire de l'égoisme', is used in the contemporary literal sense of a procession. In the source text, the idea is that Grandcourt imagines Deronda to be jealous of him and that this feeling is usually found to be metaphorically contiguous with that other feeling of a thirst for power over others. In the French text, the word 'cortège' having lost much of its figurative meaning of contiguity expresses the idea of a procession. The translator then turns the source text singular subject 'jealousy' + copula 'is' into a plural, i.e. une jalousie imaginaire et l'idée [...] agree with the plural form of the verb 'forment'. In effect, if we back translate, what we have is 'an imaginary jealousy and the idea that others sense their relative inferiority form the usual procession before egoism', a deformed and 
meaning-less translation of the source text. The examples mentioned so far were concerned with the translator setting up what Hermans (2014:291) refers to as a 'paratextual frame', here by means of an asterisk, intended to destabilise the apparent mono-lingualism of the translated text, albeit in Jumeau's translation, only half-heartedly so.

The following case of narrator's comment concerns the word éclat which is of interest because it not only involves historical development but also generates inferences related to a European heteroglossia (see Bakhtin, 1981:295). Its original meaning (1165) is derived from the verb éclater (to explode) and an éclat is a fragment of a body that has burst or exploded. From this a set of uses related to the idea of sudden outburst appear such as 'éclat de rire' $\left(17^{\text {th }}\right.$ century). As early as the $16^{\text {th }}$ century the word has connotations of a kind of violence that is visually perceived with the added sense of a bright light so that 'avec éclat' (brilliantly) is used, and so is the expression 'renommée éclatante' (glittering fame). By extension, the noun is attributed to individuals to signify liveliness, brightness so that a colour or a person can be said to 'avoir de l'éclat', or to have lost his/her shine (perdre de l'éclat). It is in the combined senses of brightness and fame that it is used in the novel, i.e. in a description of Gwendolen for whom no one can achieve true happiness without a shining reputation:

(5) And poor Gwendolen had never dissociated happiness from personal pre-eminence and éclat. (Et la pauvre Gwendolen n'avait jamais dissocié le bonheur de son succès et de son *éclat personnels, (Jumeau, $2010: 374)$ ).

As I remarked earlier (Wolf, 2015), the word éclat in the source text plunges us in the foreign grand tour and introduces a voice which carries with it very specific axiological horizons: the narrator stages a drama of 'éclat' in the novel with its inference of fragmentation (see the etymology of the word above). Gwendolen at that moment of her life has not found rest within herself. The narrator, in order to emphasise this fundamental dissonance between two voices, crosses into French to symbolise Gwendolen's alienation.

The French rendering preserves the word 'éclat', which introduces a dissonance in the text related to its marked usage in this context. The translator is then forced into a syntactic recasting which makes the adjective 'personnel' qualify 'éclat'. By so doing, the phrase 'éclat personnel' does mean something close to pre-eminence. There is however very little remaining of the inferences related to fragmentation of self.

Also involved in the generation of inferences is the passage where the word congé is used by Eliot when Deronda, visiting a Jewish bookshop in search for his friend's brother is asked by Mordecai if he is a Jew. Deronda, answers 'no' and suddenly Mordecai switches to a tone of 'distant civility': 
(6) The effect of this change on Deronda -he afterwards smiled when he recalled it- was oddly embarrassing, as if some high dignitary had found him deficient and given him his congé.

(L'effet produit par ce changement sur Deronda - il en sourit plus tard, en se le rappelant- était étrangement embarrassant et humiliant, comme si un haut dignitaire l'avait jugé inapte et lui avait donné son * congé (Jumeau, $2010: 518)$ ).

The word congé in the source text generates an array of inferences: within Mordecai's discourse, the enunciator's voice of the military dignitary is present (Wolf, 2015). The expression to give congé is a calque from the French donner congé first used in 1265 as permission to leave found in military language (Rey, 2006: 848). The use of such a locution is not random. It inserts what Bakhtin (1984: 189, cited in Rampton, 1998: 304) refers to as the 'two semantic intentions' of a discourse and generates inferences of dissonance, hence Deronda's embarrassment. More specifically, the crossing into French gives us access to the presence of two individual sociolinguistic consciousnesses, that of Mordecai as a Jew, and that of Mordecai as a dignitary. The narratorial comment here reveals the existence of different varieties of language, the language of the Jew, the language of the military, 'the languages of generations and so forth' (see Bakhtin, 1981:272). The phrase 'donner son congé' is archaic in contemporary French, i.e. the most frequent use of the phrase is a reference to paid holidays rather than military 'permission'. The inferences are similar to the English use, but they are introduced through obsolescence, instead of a composite idiom.

\section{Characters' discourse}

The majority of composite utterances in characters' speech occurred in Gwendolen's (31\%), and Hans Meyrick's speeches (17\%). We can further divide Gwendolen's mixed utterances, into two categories, those which issue directly from her and those in free indirect style. Two instances of the composite idiom in the secondary discourse of characters are in free indirect style and I would like to consider one of them as Gwendolen's expression of her subjectivity:

(7) He was adorably quiet and free from absurdities- he would be a husband en suite with the best appearance a woman could make. But what else was he? He had been everywhere, and seen everything. That was desirable, and especially gratifying [...]

In her use of en suite, Gwendolen construes Grandcourt as a consort making her look good, encoded expressively through the use of free indirect speech. The Dictionnaire Historique de la Langue Française (Rey, 2006) observes that the preposition 'en' has never preceded 'suite' in French. 
Nevertheless, the word 'suite' without the 'en' is attested with the meaning of subordinates or escort attached to a Lord in 1559 (Rey, 2006:3684) and this is how it is used in (7).

The French translation does not use Eliot's 'en suite' as this would be meaningless to French readers, and changes it to 'en accord' which erases the inference of a subordinated escort we noted earlier. Oddly enough, the target text preserves the asterisk, thus leading the French reader to assume wrongly that the phrase 'en accord' was used in the source text.

The character of Deronda uses the composite idiom systematically to reflect on a serious journey of selfrecognition in the context of religious upheaval. One example from the corpus (see table 1) illustrates this point. The word misalliance appears in a context related to the serious issues of marriage. Here Deronda mentions the word mésalliance as an echo of other enunciators' uses of it and as a way of distancing himself from the term itself ${ }^{\mathrm{ii}}$. Talking about the imminent marriage between Klesmer, the celebrated musician, and Miss Arrowpoint, he declares:

(8) If there were any mésalliance in the case, I should say it was on Klesmer's side', said Deronda.

The utterance is an echo of preceding discourse (that of Lady Penreath), and is made in order to allow Deronda to distance himself from the mentioned word. The irony of the utterance is manifest in the sense that it goes against what people would conventionally say. The use of the French word may have been for effect in Lady Penreath's speech. In Deronda's, it acquires irony and distance. These inferences of irony and distance are present in the French translation: 'S'il y avait la moindre mésalliance* en l'occurrence, je dirais qu'elle est du côté de Klesmer, dit Deronda', (Jumeau, 2010 : 13)', but the use of crossing into another language accentuates distance and irony in the source text.

The poignancy of the mixed utterance I have just observed is also manifest in those used by Hans Meyrick. Hans uses the composite idiom to display moments of social awkwardness, when his duplicity is about to be revealed. Consider, for example, his use of the phrase le néant as he explains to Deronda why he has painted Berenice seated lonely on the ruins of Jerusalem although it is not known what happened to her after she was sent away from Rome by the emperor Titus:

(9) 'I break off in the Homeric style. The story is chipped off, so to speak, and passes with a ragged edge into nothing -le néant; can anything be more sublime, especially in French?'

(et avec sa fin qui s'effiloche, elle bascule dans *le néant' -qu'y-a-t-il de plus sublime, surtout si on se sert du mot français? (Jumeau, $2010: 80)$ ). 
That the sublime character of the painting should be accentuated by the use of the French word can be understood here as Hans's attempt at irony. Indeed, in the next utterance, he distances himself from the vulgarity of those who want to see Berenice's end realistically depicted, her corpse, her burial, 'her will read and her linen distributed'. By his use of the French locution, 'can anything be more sublime, especially in French', Hans further distances himself from the vulgar enunciators who would use French to increase the sense of the sublime. This fundamentally ironic remark becomes almost meaningless in the translated text since the whole text is already in French. The sense of irony and distance cannot be fully recovered.

\section{Use of the composite idiom in a minor character's discourse}

The composite discourse of minor characters includes lexical items which are not frequent in French (see Wolf, 2015). Sir Hugo's use of the word démangeaison, for example, strikes me as particularly interesting. It has been used literally in French to refer to a state of itchiness with the corresponding verb démanger, (to itch) since 1492. Both the verb and the noun were later used figuratively to denote a need or an urge as in ça le démange around the $17^{\text {th }}$ century (Rey, 2006:2119). Sir Hugo uses it here appropriately to show how he's got rid of the expensive and compulsive habit of buying horses:

(12) '[...] and I am very glad to have got rid of that démangeaison,' said Sir Hugo as they were coming out.

The meaning of the item here is communicated weakly ${ }^{i i i}$, i.e. an array of possible inferences can be derived from the utterance and the reader is not constrained to arrive at a particular interpretation. Sperber and Wilson's (2004) example 'John has a square mind', is an illustration of how a reader can derive a great range of weak implicatures such as that John has a rigid mind, that he doesn't easily change his mind, that he is blunt and straightforwardly honest, the point being that none of these implicatures is necessary for understanding the utterance 'John has a square mind' and that metaphorical uses of words imply a certain kind of fuzziness (see Wolf, 2015). Similarly, Sir Hugo's démangeaison, weakly communicates an array of possible inferences, namely that horse-buying is compulsive like an itch, that it is a pleasurable relief, and an expensive and enslaving vice. As with a number of the characters' language crossings, this one gives the reader access to negative axiological horizons.

(13) [...] et je suis très content de m'être débarrassé de cette démangeaison*, dit Sir Hugo, lorsqu'ils sortirent. 
The translation communicates the message more strongly than in the original. In other words, the démangeaison in French is less of a metaphorical itch, less of an irresistible vice than in the source language context. The French reader does recover the metaphorical co-text, but the semantics of the word still generate medical rather than moral connotations.

\section{Discussion and concluding remarks}

The purpose of this paper was to explore some examples of the composite idiom and its translation in the novel Daniel Deronda. Over the course of the analysis, we saw how French locutions were inserted in the English text to form a double-voiced, polyphonic text which communicated a wide array of inferences weakly. Such inferences shed light on the intercultural nature of characters who went beyond the boundaries of a unitary self. Keeping this thematic focus in mind, I first sought to document the way in which the various concepts of dialogism could be seen to operate in the use of composite utterances (see Wolf, 2015).

I found three main important characteristics of the composite idiom. The idiom occurs in the majority of cases at points of conflict, if not distress, for the characters: Gwendolen is made to cross into French to symbolise alienation and her fragmented self. In a more light-hearted vein, she also uses French to mock the opposite sex or to eulogise about it again in jest. Deronda is exposed to crossings at a time of his alienation from his Jewishness, and systematically uses it to reflect his self-recognition in the context of religious allegiance. As for Hans, crossings into French tend to represent his bohemian irony and distance.

The main aim of this paper was to look at what happens to the composite idiom in translation. The point here was not only to note its quasi disappearance in a few notable cases, but also to document the effect of this vanishing act. The main contextual effect of the text being no longer mixed is that the hybrid, polyphonic and dialogical dimension of the ST originally created by means of loose inferencing and weak communication is considerably attenuated. Moreover, the ironical echoing and the distancing that follow from the use of a borrowed expression cannot be achieved in a monolingual target text. Whenever polyphony is absent from the translated text, the inferences are thereby reduced to the point of nothingness.

Given that the hybrid nature of translated texts has been fore-grounded in many recent writings on translation studies (Bhabha, 2011; Gentzler, 2008; Arduini and Nergaard, 2011), it may appear paradoxical that a translated text such as the one I have analysed should tend to erase that very hybridity. Such disappearance of mixed utterances in translated texts is all the more perplexing when there have been calls to 'radically rethink translation' (Arduini and Nergaard, 2011:13) and to situate it 
epistemologically in 'transdisciplinarity' (Arduini and Nergaard, 2011:9) in the realm of the 'interstitial' (Bhabha, 2011:20) where instability reigns and 'identities and cultures move in between, on the edges [...] in transversal movements' (Arduini and Nergaard, 2011:10). It is Steiner (1998:497) who most eloquently situates the move between languages in the realm of the ontological: "to move between languages, to translate [...] is to experience the almost bewildering bias of the human spirit towards freedom. If we were lodged inside a single 'language skin' or amid very few languages, the inevitability of our organic subjection to death might well prove more suffocating than it is'. Why then, given all of the above, we should wonder, does the double-voiced nature of Eliot's text disappear once the text is translated?

Berman's (1984:302) answer points also to the spirit of hybridity when he argues that the alleged untranslatability of poetry is dissolved into the phenomenon of translatability by means of borrowing and lexical neologism. Any translator, he argues, is fundamentally confronted to a number of choices:

'la francisation', e.g. the word 'pampa' translated as 'plaines pampasiennes', 'l'emprunt', e.g 'pampa', or 'la semi-francisation', e.g. 'Porteño' (inhabitant of Buenos Aires) becomes 'Portègne'. Indeed, hybridity is that very spirit of freedom which blows through the pages of Eliot's novel 'where it wills' (John 3:8). The problem is still how to convey the freedom of hybridity in translation.

This pessimistic sense of loss is not the note that I should like to end on. As Ricoeur (2004:19) observes in his work 'Sur la Traduction', ' en dépit de l'agonistique qui dramatise la tâche du traducteur, celui-ci peut trouver son bonheur dans ce que j'aimerais appeler l'hospitalité langagière. Son régime est donc bien celui d'une correspondance sans adéquation' (Despite the agonistic view of translation which dramatises the translator's task, one can see how he may find happiness in what I would like to call 'linguistic hospitality'. His diet then consists of correspondence without the need for equivalence.[my translation]) This linguistic hospitality derives from the pleasure one has to dwell in somebody else's language 'le plaisir d'habiter la langue de l'autre' compensated for by the pleasure one has to put the stranger up in one's own home 'le plaisir de recevoir chez soi' (Ricoeur, 2004:20).

And when the inevitable sense of loss comes about as in the departure of a favourite guest, as in the departure of a loved one, the translator must have the courage to 'faire son deuil' a French expression which means to allow for grieving to take place and to be resolved. Ricoeur (2004:41) himself uses the Freudian expression 'grief work' (travail de deuil) by which survivors find ways gradually to break the ties that bind them to the dead. Similarly in translation, grief work is applied to breaking the ties with that very ideal of the perfect translation: 'Mais travail de deuil aussi appliqué à renoncer à l'idéal même de traduction parfaite' (Ricoeur, 2004:42). 
Faced then with the shock of encountering that which is beyond comparison, 'le choc de l'incomparable' (Jullien,2001, cited in Ricoeur, 2004:63), the shock of double-voicedness, translators paradoxically are called upon to spend the appropriate time in mourning until the ties with the ideal of the perfect translation are severed, life is bearable again, and they can allow for comparison to be constructed 'la construction du comparable' (Ricoeur, 2004:66).

\section{References}

Adamson S (1994) Subjectivity in narration - empathy and echo. In: Yaguello M (ed.) Subjecthood and Subjectivity. Paris: Ophrys, 193-208.

Arduini S and Nergaard S (2011) Translation: a new paradigm. Translation: a transdisciplinary journal. Inaugural issue. Manchester: St Jerome Publishing.

Bhabha H (2011) Hybridity. Translation: a transdisciplinary journal. Inaugural issue. Manchester: St Jerome Publishing.

Bakhtin M (1981) The Dialogic Imagination. Austin and London: University of Texas Press.

Bakhtin M (1984) Problems of Dostoevsky's Poetics. Emerson C (ed. and Trans.). Minneapolis:

University of Minnesota Press.

Banfield A (1982) Unspeakable Sentences: Narration and representation in the language of fiction.

Boston: Routledge \& Kegan Paul.

Berman A (1984) L'épreuve de l'étranger. Paris : Gallimard.

Couch PJ (1967) George Eliot in France; a French appraisal of George Eliot's writings, 1858-1960.

Chapel Hill: University of North Carolina Press.

Ducrot O (1984) Le Dire et le dit. Paris: Editions de Minuit.

Eliot G (2000) Daniel Deronda. London: Everyman Classics.

Genette G (1983) Nouveau Discours du Récit. Paris: Editions du Seuil.

Gentzler E (2008) Translation and Identity in the Americas: New Directions in Translation Theory.

London: Routledge.

Haight G (1954) George Eliot Letters (9). London: Oxford University Press.

Henri-Lepage S (2003) Traduction et réception d'une auteure victorienne en France: le cas de George Eliot. TTR: traduction, terminologie, rédaction 16 (2) : 103-135.

Hermans T (2014) Positioning translators: Voices, views and values in translation.

Language and Literature 23 (3) : 285-301.

Jullien F (2001) Du temps. Paris: Grasset et Fasquelle. 
Karlin D (2005) Proust's English. Oxford: Oxford University Press.

Knapp SM (2000) 'Too intensely French for my taste': Victor Hugo as Read by George Eliot and George

Henry Lewes. In: Rignall J (ed.) George Eliot and Europe. Aldershot: Ashgate Press.

Mallarmé S (1877) Les Mots anglais. Petite philologie à l'usage des Classes et du Monde. Paris :Truchy.

Moore AW (1986) How Significant Is the Use/Mention Distinction? Analysis 46

(4):173-179.

Muysken P (2000) Bilingual Speech: A Typology of Code-mixing. Cambridge

University Press.

Pavlenko A (2004) Negotiation of Identities in Multilingual Contexts. Clevedon:

Multilingual Matters.

Pinney T (1963) Essays of George Eliot. London: Routledge and Kegan Paul.

Rampton B (1998) Language crossing and the definition of reality. In: Auer P (ed.) Code-Switching in

Conversation: Language, Interaction, and Identity. London: Routledge, 290-317.

Rey A (2006) Dictionnaire Historique de la Language Française. Paris: Le Robert.

Ricoeur P (2004) Sur la Traduction. Paris : Bayard.

Rignall J (2000) George Eliot and Europe. Aldershot: Ashgate Publishing.

Seeber H (2000) Cultural synthesis in George Eliot's Middlemarch. In: Rignall J (ed.) George Eliot

and Europe. Aldershot: Ashgate Press.

Sperber D and Wilson D (2004) Relevance Theory. In: Ward G and Horn L (eds) Handbook of

Pragmatics. Oxford: Blackwell, 607-632.

Steiner G (1975) After Babel. Oxford: Oxford University Press.

Töpffer $\mathrm{R}$ (1833) L'histoire de M. Jabot. Available at:

http://books.google.co.uk/books (accessed 7 June 2012)

Verschueren J (2008) Intercultural Communication and the Challenges of Migration.

Language and Intercultural Communication. 8 (1): 21-35.

Wolf, A. (2015): 'George Eliot's French': transcending the monocultural self in

Daniel Deronda . Language and Intercultural Communication. 15(4): 494-

512.

1This is approximate in the sense that the same French words and phrases occur many times and that some switches consist of long sequences of words which I have counted as one occurrence.

2 See the philosophical distinction between use and mention in A. W. Moore (1986) How Significant Is the Use/Mention Distinction? in Analysis Vol. 46, No. 4 (Oct., 1986), pp. 173179

3 The notion of 'weak communication' comes from the field of 'Relevance Theory' (see Sperber, Dan and Deirdre Wilson. (2004). "Relevance Theory" in G. Ward and L. Horn (eds)

Handbook of Pragmatics. Oxford: Blackwell, 607-632. 